\title{
PENINGKATAN KETERAMPILAN BERBICARA PADA KOMPETENSI DASAR BERMAIN DRAMA MELALUI MODEL JIGSAW
}

\author{
Kenang Tri Hatmo \\ SMP N 2 Sukoharjo \\ kenanghatmo@yahoo.com
}

\begin{abstract}
Abstrak
Tujuan penelitian ini adalah mendeskripsikan pelaksanaan dan peningkatan strategi model jigsaw guna meningkatkan keterampilan bermain drama pada siswa kelas VIII SMP N 2 Sukoharjo tahun Pelajaran 2015/2016. Penelitian ini menggunakan metode penelitian tindakan kelas. Subjek dalam penelitian ini adalah siswa kelas VIII SMP N 2 Sukoharjo Tahun pelajaran 2015/2016. Teknik pengumpulan data menggunakan observasi, tes, catatan lapangan, dan dokumentasi, Teknik analisis data menggunakan data model Interpretasi yaitu kegiatan menafsirkan fakta-fakta yang diperoleh dan data yang telah diseleksi pada tahap sebelumnya untuk selanjutnya dilakukan analisis data.

Hasil penelitian menunjukan pembelajaran bahasa Indonesia melalui model jigsaw jigsaw dapat meningkatkan keterampilan berbicara pada kompetensi dasar bermain drama. Hasil tes yang dicapai siswa yaitu pada siklus I sebanyak 25 siswa (62,5\%) tuntas dan pada siklus II sebanyak 36 siswa (90\%) tuntas, sehingga meningkat sebanyak 12 siswa (30\%), Keterampilan berbicara pada kompetensi dasar bermain drama pada akhir siklus II semua siswa mengalami peningkatan.
\end{abstract}

Kata Kunci : Ketrampilan Berbicara, Bermain Drama

\section{IMPROVING SPEAKING SKILL ON ROLE PLAYING COMPETENCY THROUGH JIGSAW MODEL}

\author{
Kenang Tri Hatmo \\ SMP N 2 Sukoharjo \\ kenanghatmo@yahoo.com
}

\begin{abstract}
The purposes of this research are to describe the strategic implementation and development of role playing of eight graders of SMP N 2 Sukoharjo, academic year 2015/2016. This research uses a class action research method. The subjects of this research are eight graders of SMP N 2 Sukoharjo, academic year 2015/2016. The technique of collecting the data uses observation, test, field report, and documentation. The technique of data analysis uses data interpretation, which is an activity to interpret the facts gained and data selected on the previous stage to be analyzed. The result of this research is that the strategies used in lesson of Bahasa Indonesia through jigsaw model can progress the ability of role playing. It can be seen from the students' test result on the first cycle, as many as 25 students (62.5\%) have succeed; and on the second cycle, as many as 36 students (90\%) have succeed, so it has improved as many as 12 students (30\%). At the end of the second cycle, all students have improved their speaking skill on basic competence of role playing.
\end{abstract}

Keywords:Speaking Skills, Role Playing 


\section{PENDAHULUAN}

Pada dasarnya dalam pembelajaran bahasa Indonesia di jenjang pendidikan Sekolah Menengah Pertama (SMP) secara khusus diberikan mulai di kelas I. Berbicara merupakan suatu sistem tanda-tanda yang dapat didengar dan yang kelihatan yang memanfaatkan sejumlah otot dan jaringan otot tubuh manusia demi maksud dan tujuan gagasan-gagasan atau ide-ide yang dikombinasikan. Lebih jauh lagi berbicara merupakan suatu bentuk penilaian manusia yang memanfaatkan faktor-faktor fisik, psikologis, neurologis, semantik dan linguistik sedemikian ekstensif, secara luas sehingga dapat dianggap sebagai alat manusia yang paling penting bagi kontrol sosial (Tarigan,1993:15).

Kompetensi berbicara sangat dibutuhkan untuk pengembangan prestasi atau kemampuan akademiknya. Bertitik tolak pada masalah di atas pembelajaran berbicara wajib diajarkan pada kelas VIII semester I jenjang pendidikan SMP. Indikator memerankan tokoh dengan memperhatikan lafal, intonasi, penghayatan dan ekspresi dari kompetensi dasar bermain drama sesuai dengan naskah yang disediakan. Melalui ketentuan ini, dapat dikemukakan bahwa secara teoritis siswa kelas VIII telah memiliki kompetensi sebagaimana dinyatakan dalam indikator tersebut. Sebagai institusi pendidikan formal kompetensi demikian menjadi tanggung jawab para pendidik terutama guru, kepala sekolah dan jajarannya. Dalam kehidupan sehari-hari di masyarakat, berbicara juga sangat penting. kemampuan tersebut benar-benar menjadi dasar bagi pembentukan pribadi dan keberhasilan hidupnya di tengah masyarakat.

Namun harus diakui secara jujur bahwa di kalangan siswa, khususnya di kelas VIII SMP N 2 Sukoharjo tentang keterampilan berbicara pada kompetensi dasar bermain drama belum seperti yang diharapkan. Kondisi ini tidak lepas dari proses pembelajaran bahasa Indonesia di sekolah yang dinilai telah gagal membantu siswa mengembangkan prestasinya.

Hasil Observasi di lapangan juga menunjukkan fenomena yang hampir sama, sebagian besar siswa berada dalam tingkat yang rendah dalam berbicara pada kompetensi dasar bermain drama. Dalam pandangan Lilian Herlands Hornstein dalam bukunya “The Reader's Companion to World Literature" menjelaskan bahwa 'drama' adalah 
sebuah karya sastra yang ditulis dalam bentuk dialog, dan dimaksudkan untuk dipertunjukkan oleh para pemain, pelaku, atau pemeran (Harymawan, 1981:22). Sementara itu, menurut Clay Hamilton dalam Harymawan (1981:25) bahwa "Tiap drama merupakan suatu cerita, yang dikarang dan disusun untuk dipertunjukkan oleh pelaku-pelaku di atas penggung di depan publik".

Demikian juga, sebagian besar siswa kelas VIII SMP Negeri 2 Sukoharjo tahun Pelajaran 2015/2016. Indikator yang digunakan untuk mengukur keberhasilan siswa adalah keterampilan berbicara pada kompetensi dasar bermain drama dari aspek lafal, intonasi, penghayatan, dan ekspresi dengan melihat hasil belajar siswa dengan standar ketuntasan belajar minimal.

Kenyataan di lapangan dari pengamatan dan berdasarkan hasil informasi dari kegiatan sharing yang khusus dilakukan dengan sesama teman guru kemampuan sebagian siswa masih sangat rendah keterampilan berbicaranya. Hal ini dapat dilihat melalui nilai harian di kelas tersebut. Dari jumlah siswa 40 orang yang nilainya cukup memadai dalam berbicara kompetensi dasar bermain drama baru
$30 \%$ (12 orang), sisanya $70 \% \quad$ (28 orang) masih sangat memprihatinkan. Indikator rendahnya dalam hal ini dapat dilihat pada rendahnya siswa dalam aspek berbicara dan menulis.

Jika kondisi pembelajaran semacam itu dibiarkan berlarut-larut, bukan tidak mungkin terjadi di kalangan siswa SMP akan terus berada pada tataran yang rendah. Para siswa akan terus-menerus mengalami kesulitan dalam mengekspresikan kreatifitasnya.

Konteks demikian, diperlukan pendekatan model jigsaw yang benarbenar inovatif dan kreatif sehingga proses pembelajaran bisa berlangsung aktif, efektif, dan menyenangkan. Siswa tidak hanya diajak untuk belajar, berlatih dalam konteks dan situasi tutur yang sesungguhnya dalam suasana yang dialogis, interaktif, menarik, dan menyenangkan. Dengan cara demikian, siswa tidak akan terpasung dalam suasana pembelajaran yang kaku, monoton, dan membosankan. Pembelajaran keterampilan berbicara pun menjadi sajian materi yang selalu dirindukan dan dinantikan oleh siswa.

Menurut Priyanto Pembelajaran kooperatif adalah pembelajaran yang secara sadar menciptakan interaksi yang silih asah sehingga sumber belajar bagi 
siswa bukan hanya guru dan buku ajar, tetapi juga sesama siswa (Nurhadi dan Senduk, 2003). Oleh karena itu, langkah real dalam melakukan model jigsaw adalah sebagai berikut (Priyanto, 2007).

Langkah pertama, Pembentukan Kelompok Asal yaitu tahapan dengan setiap kelompok asal terdiri dari 4-5 orang anggota dengan kemempuan yang heterogen. Pembelajaran pada Kelompok Asal yaitu setiap anggota kelompok asal mempelajari submateri pelajaran yang akan menjadi keahliannya, kemudian masing-masing mengerjakan tugas secara individual. Kedua, Pembentukan Kelompok Ahli yaitu ketua kelompok asal membagi tugas kepada masingmasing anggotanya untuk menjadi ahli dalam satu submateri pelajaran. Kemudian masing-masing ahli submateri yang sama dari kelompok yang berlainan bergabung membentuk kelompok baru yang disebut kelompok ahli. Ketiga, Diskusi Kelompok Ahli yaitu anggota kelompok ahli mengerjakan tugas dan saling berdiskusi tentang masalahmasalah yang menjadi tanggung jawabnya. Setiap anggota kelompok ahli belajar materi pelajaran sampai mencapai taraf merasa yakin mampu menyampaikan dan memecahkan persoalan yang menyangkut submateri pelajaran yang menjadi tanggung jawabnya. Keempat, Diskusi Kelompok Asal (Induk) yaitu anggota kelompok ahli kembali ke kelompok asal masingmasing. Kemudian setiap anggota kelompok asal menjelaskan dan menjawab pertanyaan mengenai submateri pelajaran yang menjadi keahliannya kepada anggota kelompok asal yang lain. Ini berlangsung secara bergilir sampai seluruh anggota kelompok asal telah mendapatkan giliran. Kelima, Diskusi Kelas yaitu dengan dipandu oleh guru diskusi kelas membicarakan konsep-konsep penting yang menjadi bahan perdebatan dalam diskusi kelompok ahli. Guru berusaha memperbaiki salah konsep pada siswa. Keenam, Pemberian Kuis yaitu kuis dikerjakan secara individu. Nilai yang diperoleh masing-masing anggota kelompok asal dijumlahkan untuk memperoleh jumlah nilai kelompok. Ketujuh, Pemberian Penghargaan Kelompok yaitu Kepada kelompok yang memperoleh jumlah nilai tertinggi diberikan penghargaan berupa piagam dan bonus nilai.

Jadi, model jigsaw adalah suatu pembelajaran yang memiliki keunggulan yaitu pembagian tugas pada setiap kelompok dapat dioperasikan. Siswa 
memperoleh kesempatan untuk mengungkapkan pengetahuannya tentang informasi yang dipelajari melalui kegiatan kelompok, baik kelompok asal maupun kelompok ahli. Siswa terlibat dalam kerjasama kelompok sehingga siswa yang berkemampuan rendah memiliki tanggung jawab yang sama terhadap kesuksesan hasil kerja kelompoknya.

Oleh sebab itu, penelitian ini bertujuan untuk mendeskripsikan pelaksanaan-pelaksanaan model jigsaw guna meningkatkan keterampilan berbicara pada kompetensi dasar bermain drama siswa kelas VIII SMP Negeri 2 Sukoharjo tahun Pelajaran 2015/2016. Selain itu, bertujuan untuk mendeskripsikan peningkatan keterampilan berbicara pada kompetensi dasar bermain drama siswa kelas VIII SMP N 2 Sukoharjo tahun Pelajaran 2015/2016 yang disampaikan melalui model jigsaw.

\section{METODE PENELITIAN}

Desain pada penelitian ini adalah Penelitian Tindakan Kelas dengan setiap siklus meliputi terdiri dari (a) perencanaan, (b) pelaksanaan, (c) pengamatan, (d) refleksi. Subyek penelitian ini yaitu guru bahasa
Indonesia dan siswa kelas VIII SMP Negeri 2 Sukoharjo. Jumlah siswa yang menjadi subjek penelitian tersebut sebanyak 40 anak, terdiri dari 15 siswa laki-laki dan 25 siswa perempuan.

Instrumen pengumpulan data dalam PTK ini yaitu: (1)Lembar Observasi yaitu mengamati langsung kegiatan yang diteliti dengan tujuan untuk memproleh data mengenai kinerja guru dan aktifitas siswa selama berlangsungnya pembelajaran berbicara pada bermain drama dengan model jigsaw. Berdasarkan data hasil observasi ini maka dapat ditentukan rencana tindakan selanjutnya. (2)Lembar Wawancara yaitu untuk menanyakan terhadap kejadian, kegiatan, perasaan, motivasi, dalam kegaiatan bermain drama dengan model jigsaw yang dilakukan dengan guru dan siswa tentang peningkatan kemampuan bermain drama dengan model jigsaw. (3)Catatan Lapangan yaitu mencatat informasi-informasi atau kejadiankejadian selama berlangsungnya proses pembelajaran bermain drama melalui pembelajaran kooperatif model jigsaw, yang terkait dengan adanya tindakan yang bersifat kualitatif. (4)Observasi/rubrik penilaian yaitu mendata kemampuan berbicara 


\section{HASIL DAN PEMBAHASAN}

Berdasarkan hasil yang didapat, pada pembelajaran bahasa Indonesia khususnya berbicara pada kompetensi dasar bermain drama sebelum menggunakan model jigsaw yang dinilai dari aspek lafal, intonasi, penghayatan, ekspresi diperoleh data siswa nilainya belum lulus 25 siswa(62,5\%) dan yang lulus 15 siswa $(37,5 \%)$.

Berdasarkan hasil siklus I dapat dilihat bahwa, pada pembelajaran bahasa Indonesia khususnya berbicara pada kompetensi dasar bermain drama yang dinilai dari aspek lafal, intonasi, penghayatan, ekspresi diperoleh data siswa nilai lulus 25 siswa $(62,5 \%)$ dan tidak lulus 15 siswa $(37,5 \%)$. KKM (Ketuntasan Kelulusan Minimal) untuk mata pelajaran bahasa Indonesia adalah 65. dari data diatas yang diperoleh maka dapat ditentukan bahwa terdapat 15 siswa $(37,5 \%)$ belum memenuhi standar KKM. Nilai rata-rata kelas siklus I adalah 68,10 .

Pada siklus II siswa betul-betul paham dengan model jigsaw jigsaw dan merasa senang, terbukti dengan nilai kurang pada aspek lafal, intonasi, penghayatan dan ekspresi siswa kelas VIII SMP N 2 Sukoharjo tahun
Pelajaran 2015/2016 hanya pada aspek intonasi ada 2 siswa (5\%) yaitu kode siswa X.1, X.29 dan aspek ekspresi 3 siswa $(7,5 \%)$ yaitu kode siswa X.5, X.10, X.16. hal ini dapat dilihat pada tabel 11.

Berdasarkan pelaksanaan prasiklus, siklus I dan siklus II dapat diketahui bahwa penerapan model jigsaw dapat meningkatkan hasil belajar siswa, khususnya dalam peningkatan keterampilan berbicara pada kompetensi dasar bermain drama pada pembelajaran Bahasa dan Sastra Indonesia pada kelas VIII. Sesuai hasil penelitian indikator keberhasilan untuk meningkatkan keterampilan berbicara pada kompetensi dasar bermain drama dengan penerapan model jigsaw apabila $90 \%$ dari siswa sudah mencapai kriteria ketuntasan minimal dengan batas tuntas 6,5.

Berikut adalah grafik peningkatan keterampilan berbicara pada kompetensi dasar bermain drama dengan menerapkan pembelejaran kooperatif model jigsaw sebagai berikut: 


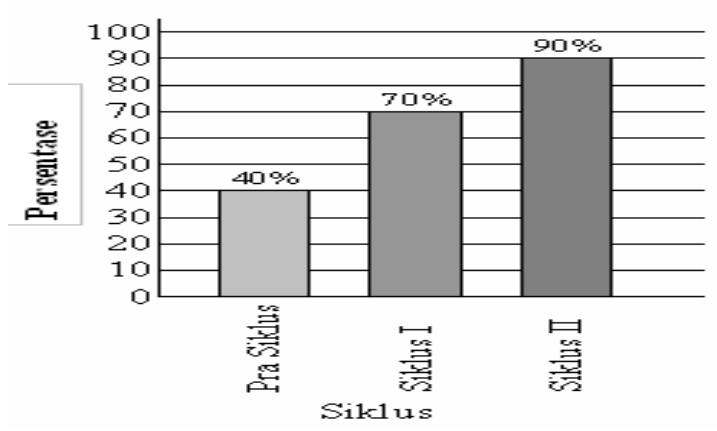

Gambar 1. Grafik Nilai Ketrampilan Berbicara pada Pra Siklus, Siklus I, Siklus II.

\section{SIMPULAN}

Berdasarkan hasil analisis data di atas, dapat disimpulkan bahwa: Pertama, Penggunaan model jigsaw dalam pembelajaran keterampilan berbicara pada kompetensi dasar bermain drama menunjukkan adanya perbedaan yang signifikan antara kemampuan awal dengan prestasi hasil belajar setelah adanya tindakan. Hasil observasi selama pembelajaran menunjukkan peningkatan jumlah siswa dan peningkatan persentase siswa berdasarkan atas penilaian beberapa aspek. Hasil observasi dalam bentuk skor juga mengalami peningkatan baik peningkatan motivasi siswa secara individu maupun peningkatan motivasi siswa dalam kelompok satu kelas.
Kedua, Pencapaian hasil belajar siswa kelas VIII SMP N 2 Sukoharjo dalam keterampilan Berbicara pada kompetensi dasar bermain drama juga mengalami peningkatan. Jumlah nilai dan rata-rata menunjukkan peningkatan, yaitu pada tahapan pra siklus rata-rata siswa $=61,42$, siklus $I=68,33$, dan siklus $\mathrm{II}=76,68$. Persentase pencapaian ketuntasan belajar pada keterampilan berbicara pada kompetensi dasar bermain drama siswa kelas VIII SMP N 2 Sukoharjo dari tiap-tiap siklus juga menunjukkan peningkatan. Pada tahap pra siklus persentase ketuntasan $=40 \%$. Pada tindakan siklus $\mathrm{I}=70 \%$. Dan tindakan siklus II persentase ketuntasan belajar $=90 \%$.

\section{DAFTAR PUSTAKA}

Abbas, Saleh. 2006. Pembelajaran Bahasa Indonesia Yang Efektif. Jakarta:Departemen Pendidikan Nasional.

Ahmadi, Mukhsin. 1990. Strategi Belajar Mengajar Ketrampiulan Berbahasa dan Apresiasi Sastra. Malang:YA 3 Malang.

Akhadiah, S. dkk. 1991. Bahasa Indonesia III. Jakarta: Depdikbud. Aqib, Zaenal dan Diniati, Eko. 2008. Penelitian Tindakan Kelas (PTK) 
untuk Guru SMP, SMA, SMK. Bandung:Yaam Widya.

Dediknas. 2005. Bahasa dan Sastra Indonesia Materi Terintegrasi. Jakarta: Depdiknas.

Depdiknas. 2008. Kurikulum Tingkat Satuan Pendidikan.

Jakarta:Depdiknas.

Djuanda, D. 2008. Pembelajaran Keterampilan Berbahasa

Indonesia. Bandung:Pustaka Latifah.

FKIP Univet. 2009. Pedoman Teknik Penulisan Skripsi Jurusan Pendidikan Bahasa dan Seni. Sukoharjo:FKIP Univet.

FKIP Univet. 2008. Klitika Jurnal Pendidikan dan Pembelajaran Bahasa dan Sastra. Sukoharjo : FKIP Univet.

Haryadi, Zamzani. 1997. Peningkatan Keterampilan Berbahasa Indonesia. Jakarta:Depdikbud.

Harymawan, RMA. 1988. Dramaturgi. Bandung:CV Rosda.

Sanjaya, Wina. 2006. Strategi Pembelajaran Berorientasi Standar Proses Pendidikan. Jakarta:Kencana Prenada Media. Satoto, Soediro. 1993. Kajian Drama. Surakarta:STSI Press.
Sukidin. 2008. Manajemen Penelitian Tindakan Kelas. Jakarta:Insan Cendikia.

Suprijono, Agus. 2009. Cooperative Learning, teori dan Aplikasi Paikem. Yogyakarta:Pustaka Pelajar.

Susilo, Herawati dan Chotimah Husnul dan Dwitasari, Yuyun. 2000. Penelitian Tindakan Kelas Sebagai Sarana Pengembangan Keprofesionalan Guru dan Calon Guru. $\quad$ Malang:Bayumedia Publishing.

Waluyo, Hermawan J. 2001. Drama Teori dan Pengajarannya. Yogyakarta:PT. Hanindita Graha Widya. 